\title{
Complexities of translating mathematics tasks from English to learners' home languages
}

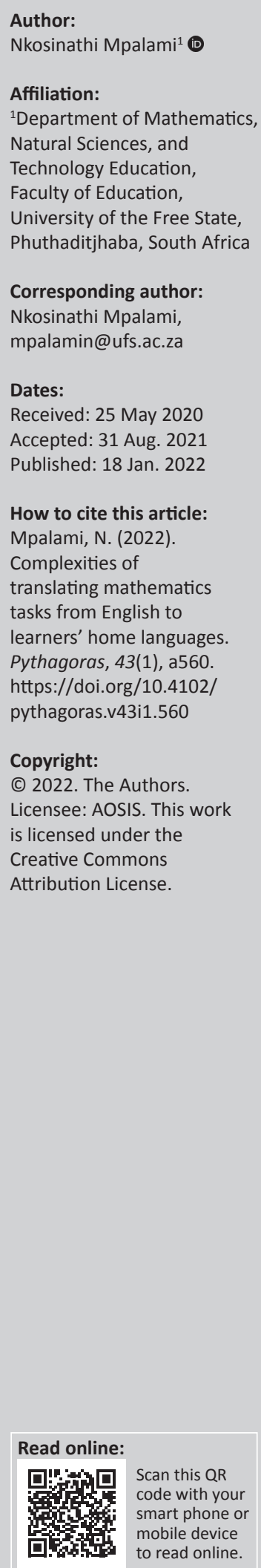

\begin{abstract}
Mathematics education remains problematic in South Africa's schools. However, some mathematics educators are deliberately using learners' home languages in tasks to assist learners to understand mathematics. Research-based evidence shows that learners' home languages when used as a resource have a potential to enhance learners' understanding of mathematics. This article addresses the issue of translating mathematics tasks from English to learners' home languages, a field that is less common in mathematics education studies. The study shows that there are complexities associated with such translation which all stakeholders in education should bear in mind. The article does so by referring to a study where a Grade 11 mathematics educator in a multilingual class tried to use learners' home languages in tasks with an aim to enhance learners' understanding of linear programming concepts. The study was conducted in township school in Gauteng province. Ethical clearance was given by the Gauteng Department of Education. Data were collected through observations and were analysed qualitatively. The situated sociocultural perspectives guided the study. The findings show that during the translation process, the educator went as far as translating mathematics technical terms. Such translation distorted the meaning of the original task and therefore made it hard for learners to comprehend concepts as envisioned. The recommendation is that the translation should not be left to individual mathematics educators but rather there should be a broader approach of having mathematics tasks translated from English into other official languages and such tasks be distributed to all schools throughout the country. Professional translators must also be contracted to do such a job.
\end{abstract}

Keywords: Multilingual classrooms; linear programming; home languages; mother tongue; mathematics tasks; translated tasks.

\section{Introduction}

This article addresses the issue of translating mathematics tasks from English language to learners' home languages. The article shows that the work of translating mathematics tasks is challenging, and care must be taken when such an activity takes place. Recent reports indicate that South African learners' performance in mathematics continues to be undesirable. When assessing the state of mathematics and science education, the World Economic Forum (WEF) Report $(2017 / 18)$ mentions that South Africa is ranked 128th out of 137 countries in the Global Competitiveness Rankings (http://reports.weforum.org/pdf/gci-2017-2018scorecard/WEF_GCI_2017_2018_Scorecard_EOSQ130.pdf). Furthermore, in the year 2018, out of the 800843 learners who sat for the National Senior Certificate examination, 21\% obtained a bachelor's pass which was significantly low. According to the Trends in International Mathematics and Science Study (TIMSS) 2002 and TIMSS 2011, South African students are ranked among the lowest (Saal, Van Ryneveld \& Graham, 2019). This crisis calls for immediate intervention by all stakeholders in education. While there could be multiple solutions to this problem, learners' understanding of key mathematics concepts in their home languages remains critical (Nhongo \& Tshotsho, 2019). When arguing from a 'translanguaging' perspective, Nhongo and Tshotsho (2019, p. 58) point out that 'it is an undoubtable fact that a learner understands better when concepts are introduced to him or her in his or her first language'. It could be reasoned that translating mathematics tasks into learners' home languages is a positive move towards helping African learners whose mother tongue is not English or Afrikaans in South Africa to gain a better understanding of mathematics. This implies that all 'linguistic resources' in multilingual classrooms must be used 'flexibly and contingently to facilitate effective communication' (Costley \& Leung, 2020 , p. 2). This point again drawn from translanguaging studies reinforces the notion that people communicate effectively when they interact in their home languages rather than when they talk in the language of others. 


\section{Purpose of study}

The study was set to explore the complexities associated with translating mathematics tasks from English to learners' home languages, and how such translated tasks were used in a multilingual classroom. Stein, Grover and Henningsen (1996, p. 460) define a mathematics task as 'a classroom activity, the purpose of which is to focus students' attention on a particular mathematical idea'. In the teaching and learning of mathematics, a teacher plays an important role in selecting or creating appropriate tasks for learners. The commonly used mathematics tasks are readily available in English. Mathematics educators have a responsibility to assist learners to unpack the demands of such tasks. One way of doing that might be using multiple learners' home languages. Prior to a democratic South Africa, the only legal languages used for instruction were Afrikaans and English which inevitably advantaged the speakers of those languages. However, in this era teachers are at liberty to use any official language to help learners understand mathematical concepts (Planas \& SetatiPhakeng, 2014). While 'code-switching' might be regarded as a common practice in multilingual classrooms (Setati, 2005b), the work of translating tasks is rare and limited in the field of mathematics education. Tesseur and Crack (2020) point out that translation in general is not a common practice in a variety of contexts such as in education. This article hopes to contribute some insights in the field of mathematics education. The teacher in the study used translated tasks in a lesson with an aim to make linear programming concepts accessible to African learners.

\section{The research question}

The research question that guided this study was:

What are the complexities associated with translating mathematics tasks from English into learners' home languages?

\section{Statement of problem}

While translation may be narrowly viewed as 'linguistic equivalence between two languages', cultural contexts must be considered during the process of translation (Chibamba, 2018). Translation studies scholars concur that multilingual settings necessitate the process of translation (Marais, 2014; Nord, 1997; Tesseur \& Crack, 2020).

These studies, however, have not provided guidance as to how translated tasks might be used for teaching purposes. The South African Department of Education (DBE) (2011) stresses the need for educators to use learners' home languages in class to help them comprehend subject matter. What remains unclear is how such languages must be used during instruction. If the official documents remain silent on this issue, then it becomes challenging for individual educators to know how they should begin using such languages. When drawing from Setati (2008), Barwell (2016) reminds us that the use of language in class should never be taken for granted as it has a potential to either 'privilege or marginalize' some learners. That is why it is imperative for instructional documents to spell out clearly how educators must make use of multiple languages in mathematics lessons.

In this article, a class is regarded to be multilingual if participants (learners and educators) are potentially capable of drawing on more than one language as they interact during a lesson (Setati \& Barwell, 2006). Given that South Africa is a rainbow nation, it then follows that several schools are either bilingual or multilingual. Even though African learners have their own home languages, researchers have established that they continue to be taught mathematics in either English or Afrikaans (Setati, 2005; Webb \& Webb, 2008). It is also known that most educators in this country are fluent in at least two languages (Adler, 2001). Adler argues that educators in South Africa are faced with this 'dilemma' frequently: to either pay more attention to mathematical language or to focus on mathematical concepts. Barwell (2003) poses this question: how best should mathematics educators use multiple languages in instruction? We could further ask how such use must support and enhance learners' understanding of mathematical concepts.

\section{Rationale}

Unlike many other mathematics topics, linear programming has a lot of word problems that require learners to deeply understand the demands of each task so that they can form multiple representations (ed. Luneta, 2018; Mpalami, 2013; Purwadi, Sudiarta \& Suparta, 2019) as steps leading to a solution. Tshuma (2020) highlights the role language plays in mathematics education by either making mathematics accessible to learners or hindering their advancement in mathematics. Learners must master both the ordinary language used in tasks and the mathematical register thereof. According to Sepeng (2014, p. 15), 'mathematical word problems include pure mathematical tasks dressed up in a real-world situation'. Then learners' duty remains mainly to analyse and successfully find solutions. Unpacking the demands of each word problem is linguistically challenging for learners, especially for those who study mathematics in a language that is not their own (Moschkovich, 2009; Setati, 2005a; Tshuma, 2020). Added difficulty is because most word problems use mathematical language, as will be seen later in this article. The translation effort in this study was based on the premise that if learners understand tasks in their home languages, then they might be in a better position to solve them successfully. However, Chibamba (2018) cautions that translation is a challenging process in that no translation will possibly be congruent to its original text. In this study, a mathematics task was translated from English into several home languages that existed in the class, and those languages were isiZulu, isiXhosa, Sepedi and Sesotho.

\section{Literature review}

The situated sociocultural perspective to learning and teaching informed this study. Moschkovich (2002, p. 197) argues that: 
a situated-sociocultural perspective can be used to describe the details and complexities of how students, rather than struggling with the differences between the everyday and the mathematical registers or between two national languages, use resources from both registers and languages to communicate mathematically.

In this study, it was helpful to understand how the educator used learners' home languages in tasks as linguistic resources. Because learning mathematics is inherently social and cultural (Moschkovich, 1999), it was important to understand how the translated versions made it easier for learners to participate in class. Moschkovich (2002) outlines four constructs embedded within a situated sociocultural framework. Those are 'practices, bi/multilingualism, code switching, and discourses'. These four intertwined notions might help researchers to understand interactions that take place in multilingual mathematics lesson. As an analytical lens, the four dimensions were used to provide analysis of the translated task and how such translation might have impacted on its use during instruction. The notion of 'practices' assisted in focusing on the content under discussion. Some of the mathematical practices are abstracting, generalising, explaining, and connecting claims to representations.

The code switching dimension assisted in explaining the differences and similarities that exist between the two versions of the same task because the translation process was mainly between two languages, namely English and a home language. The multilingualism dimension shed light on the nature of the languages that existed in this particular Grade 11 class. The discourse dimension made it possible to analyse words that were used in the translated tasks whose meaning could be situated in the community and culture where such language is spoken.

Contentions about the choice of language of instruction in South African schools were raised in the early 2000s by researchers (Setati, 2003). Setati (2005b) highlights the point that despite the efforts that South Africa's government is putting in place to give African languages the status they deserve, many parents continue to prefer English as a medium of instruction for their children. This is no surprise because as Setati puts it 'mother tongue instruction' is viewed as of less importance among speakers of African languages. They associate it with the historic apartheid regime where African languages were considered inferior and not suitable for use in teaching and learning. Setati further states that English remains the language of socioeconomic and educational development in South Africa. Of course, this is not unique to Africa: Sahr (2020:54) when doing research with German students concludes that 'speaking English is clearly connected with "Americanness" and whiteness'. Setati (2008) has termed this powerful status of English a 'cultural model'. Barwell (2016, p. 36) concurs with Setati and argues that the very same 'cultural model of English as an international language is political in nature, as it privileges a particular language and people who are able to use it effectively'.
The cultural model of English helps us understand why some African parents want their children to learn English and to be taught subjects like mathematics in English. It is the very same cultural model of English that influences educators' daily decisions regarding the language they choose to use in mathematics teaching. When referring to their study carried out in the Eastern Cape, Webb and Webb (2008, p. 29) remind us that even educators themselves share a similar view about the use of learners' home language (isiXhosa) during instruction. They therefore argue that educators 'expressed the fear that by using code switching they are depriving their learners of opportunities associated with the use of English'. However, some scholars who advocate for 'translanguaging' pedagogy support the use of learners' home languages for teaching and learning (Aoyama, 2020; García, 2009; Sayer, 2013). Translating mathematics tasks therefore remains pertinent for African learners.

\section{Methodology}

This study employed qualitative approaches (Cohen \& Manion, 1994). A Grade 11 mathematics educator who was teaching in a multilingual classroom agreed to participate in the study. He agreed that data be collected at the time when he was teaching linear programming. He deliberately utilised African languages in tasks to enhance learners' understanding, a trait that made him relevant to this study. This was an 'exemplifying case study' (Bryman, 2008) whose focus was to capture and explore circumstances and conditions of an individual teacher and his ways of teaching a particular mathematics concept. According to Mouton (2001, p. 149) case studies are 'studies that are usually qualitative in nature and that aim at providing an in-depth description of a small number of cases'. So, the assumption here is that by focusing on a 'case' one is likely to acquire a deeper understanding of the phenomenon.

The mathematics tasks that the educator used in each lesson formed the main source of data in the study. Such tasks were collected and later analysed. However, for this article the focus is mainly on the task used in Lesson 5. It is in this lesson where the educator used translated versions of the task. The teacher asked his colleagues from the language department to help with the translation of the task from English to learners' home languages. The translated tasks were then taken to his mathematics teachers for validation. The tasks were piloted with 11 Grade 12 learners representing the four ethnic groups. This was to ensure that such tasks were suitable for use in class. During the lesson, learners worked on the task in groups as follows: two Sepedi groups, two Sesotho groups, one isiXhosa group, and one isiZulu group. The Gauteng Department of Education granted ethical clearance to carry out this study.

\section{Discussion of data and results}

In this section, the analysis of each version of the task is done separately to pinpoint to the complexity in each translated task. 
TABLE 1: Mathematics task in original English and translation.

\begin{tabular}{|c|c|c|c|c|}
\hline Task in English & Task in isiZulu & Task in isiXhosa & Task in Sepedi & Task in Sesotho \\
\hline $\begin{array}{l}\text { (a) } \\
\text { (i) A farmer buys } x \text { dairy cows at } \\
\text { R1250 each and } y \text { beef cows at } \\
\text { R1000 each. He can spend up to } \\
\text { a maximum of R5000. Write this } \\
\text { information as an inequality in } \\
x \text { and } y \text {. }\end{array}$ & $\begin{array}{l}\text { (a) } \\
\text { (i) Umlimi othize uthenga } \\
\text { izinkomo zobisi esingazazi ukuthi } \\
\text { zingaki, iyinye ibiza inkulungwane } \\
\text { namakhulu amabili anamashumi } \\
\text { amahlanu amarandi (R1250) } \\
\text { kanye nezenyama } \\
\text { ezingadalulwanga ukuthi zingaki } \\
\text { kodwa iyinye ibiza inkulungwane } \\
\text { yamarandi. Imali angayisebenzisa } \\
\text { ukuthenga izinkomo zobisi } \\
\text { nezenyama iyizinkulungwane } \\
\text { ezinhlanu zamarandi (R5000). } \\
\text { Sicela usibhalele ama } \\
\text { 'inequalities' mayelana } \\
\text { nezinkomo zobisi nezenyama. }\end{array}$ & $\begin{array}{l}\text { (a) } \\
\text { (i) Umlimi uthenge iinkomo } \\
\text { zobisi ezinga, inye ixabisa iwaka } \\
\text { elinamakhulu amabini } \\
\text { anamashumi amahlanu (R1250) } \\
\text { waze wathenga iinkomo } \\
\text { zenyama ezinga, inye ixabisa } \\
\text { iwaka leerandi (R1000). } \\
\text { Angachitha kangangamawaka } \\
\text { amahlanu (R5000) Yenza } \\
\text { umlinganiselo weenkomo } \\
\text { zobisi nowenkomo zenyama. }\end{array}$ & $\begin{array}{l}\text { (a) } \\
\text { (i) Molemi o reka dikgomo tša } \\
\text { maswi tše sa tsebjego gore ke } \\
\text { tše kae, fela e tee ke R1250 le } \\
\text { tša nama tše sa tsebjego, e tee } \\
\text { e lego R1000. A ka šomiša } \\
\text { tšhelete ye lekanego R5000. } \\
\text { Ngwala tekatekanyetšo ka } \\
\text { dikgomo tše sa tsebjego tša } \\
\text { lebese le tša nama. }\end{array}$ & $\begin{array}{l}\text { (a) } \\
\text { (i) Rapolasi o reka dikgomo tsa } \\
\text { lebese ka R1250 e le nngwe le } \\
\text { dikgomo tsa nama ka R1000. } \\
\text { Tjhelete e kahodimo eo a ka e } \\
\text { sebedisang ke R5000. Beha } \\
\text { ditaba tsena jwaloka kgaello ya } \\
\text { dikgomo tsa lebese le tsa nama. }\end{array}$ \\
\hline $\begin{array}{l}\text { (ii) Write down any other } \\
\text { inequalities implicit in the } \\
\text { situation. }\end{array}$ & $\begin{array}{l}\text { (ii) Singajabula uma } \\
\text { ungasibhalela amanye ama } \\
\text { 'inequalities' maqondana ne } \\
\text { ngxoxo ingenhla ekubeni futhi } \\
\text { layo ma "inequalities" ebeka } \\
\text { imigomo ethize. }\end{array}$ & $\begin{array}{l}\text { (ii) Yenza omnye womlinganiselo } \\
\text { ngalengxelo ingentla. }\end{array}$ & $\begin{array}{l}\text { (ii) Ngwala ditšhitišo tše dingwe } \\
\text { mabapi le polelo ye ka godimo. }\end{array}$ & $\begin{array}{l}\text { (ii) Ngola di kgaello tse ding tse } \\
\text { ka hlahellang maemong ana a } \\
\text { ditaba tse ka ho dimo. }\end{array}$ \\
\hline $\begin{array}{l}\text { (iii) Can } x \text { and } y \text { take on any real } \\
\text { values? Explain. }\end{array}$ & $\begin{array}{l}\text { (iii) Kungabe izinkomo ezidaluliwe } \\
\text { zingabalelwa ezintweni ezikhona } \\
\text { noma ezingekho? Kungani chaza. }\end{array}$ & $\begin{array}{l}\text { (iii) Ingaba iinkomo zobisi } \\
\text { nezenyama zingasinika owuphi } \\
\text { umlinganiselo? Chaza. }\end{array}$ & $\begin{array}{l}\text { (iii) Go a kgonagala gore tše sa } \\
\text { tsebjego go tša maswi le tša } \\
\text { nama di gona ka nnete? Hlaloša } \\
\text { karabo ya gago. }\end{array}$ & $\begin{array}{l}\text { (iii) Na dikgomo tsa lebese le } \\
\text { dikgomo tsa nama e ka ba } \\
\text { manane a nnete? Hlalosa. }\end{array}$ \\
\hline $\begin{array}{l}\text { (b) Graph the inequalities to } \\
\text { show the feasible region. }\end{array}$ & $\begin{array}{l}\text { (b) Bonisa umdwebo omuhle } \\
\text { lapho, lama 'inequalities' } \\
\text { ehlangana khona enze isithombe } \\
\text { esisibiza ngokuthi I 'feasible } \\
\text { region' [isifunda soxazululo]. }\end{array}$ & $\begin{array}{l}\text { (b) Zoba lengxelo phantsi } \\
\text { ubonakalise ukuba isonjululwa } \\
\text { njani ukubonisa 'feasible region'. } \\
\text { [Ummmango wesisombululo] }\end{array}$ & $\begin{array}{l}\text { (b) Laetša ka sethalwa gore mo di } \\
\text { kopanago di dira 'feasible region'. } \\
\text { [sekgutloana tharollo] }\end{array}$ & $\begin{array}{l}\text { (b) Bontsa dikgaello tse ka } \\
\text { hodimo ka graph; o bontshe le } \\
\text { di 'feasible region'. [lesakana } \\
\text { tharollo] }\end{array}$ \\
\hline
\end{tabular}

\section{Complexities of translating tasks}

Table 1 presents the translated tasks together with the original task taken from the textbook. Learners were given the tasks to work on in their respective groups. Their discussions were based on both the English version and the translated version. The educator moved from one group to another listening to how learners were reasoning about the task. However, while the educator was able to understand some of the home languages his main language is isiZulu.

The task could be referred to as a 'real-life mathematical word problem without real context' (Sepeng, 2014). In part (a) the cost prices for cows are not realistic. The cheapest beef cow might not necessarily cost R1000 in South Africa. However, this should never affect learners' ability to solve the problem. The task has realistic mathematical demands irrespective of its unrealistic context. It must be mentioned here that the educator's home language is isiZulu which then suggests that the isiZulu version might be the best translation compared to the others.

The following discussion pays attention to each translated version. The discussion is not meant to expose the teacher's weaknesses, but rather to understand the complexities associated with translating mathematics tasks.

\section{Task in isizulu}

The two variables $x$ and $y$ are mentioned in the English task. In mathematics, $x$ and $y$ are symbols that represent various unknowns. In the task, $x$ stands for a certain number of dairy cows and $y$ for beef cows. It is worth noting that in the isiZulu version $x$ and $y$ were translated into words. The teacher wrote the word esingazazi [unknown] for $x$ and then translated $y$ as ezingadalulwanga [anonymous]. This type of translation makes these two variables look like they were words that had to be translated. However, in (a)(iii) the translation for both $x$ and $y$ is the word ezidaluliwe (anonymous). Such an inconsistency has the potential of complicating the task and confusing learners. Again, in the isiZulu version the amount R1000 is not written in figures like in the English version. It is translated as inkulungwane yamarandi (one thousand rands). But other amounts are presented both in words and numerals. This inconsistency might be confusing. However, in the isiZulu version the technical word inequality is not translated and rather used in context. The use of this technical term in this manner might indicate to isiZulu learners that they must construct constraints (inequalities) and later represent them on the Cartesian plane to show a feasible region. The use of the word inequality might as well have lowered the complexity of task and made it easier to comprehend.

The isiZulu translation in this case seems to be more personal than the original version. For example, in part (a)(ii) the task reads: 'Singajabula uma ungasibhalela amanye ama inequalities ...' [We can be happy if you can write other inequalities .... . Being 'glad' was never part of the original task. The original task reads: 'Write down any other inequalities ...'. This incident indicates that translating mathematics tasks is complex. This type of translation might limit learners' ability to comprehend mathematics content. The personal style of translation could be entrenched in the Zulu culture, especially the way a teacher would relate to a group of Zulu learners. Such a practice does not exist in the English language. In general, that would be a polite way a person gives instructions to those he respects. This personal style therefore serves as a way of encouraging learners to actively participate in doing the task. However, the shortcoming of this style is that it increases the number of words in a task and therefore might make it hard to establish the actual demands of the task. 


\section{Task in isiXhosa}

In the isiXhosa version the word ezinga [unknown] was used for both $x$ and $y$ during translation (see (a)(i)). However, in part (a)(iii), the same word is not used for $x$ and $y$. When looking at the two sections part (a)(iii) is clearer than section (a)(i). For instance, part (a)(i) reads:

Umlimi uthenge iinkomo zobisi ezinga. Inye ixabisa iwaka elinamakhulu amabini aneshumi elinesihlanu (R1250) [the verbalization of 1250 is not linguistically correct here]. waze wathenga iinkomo zenyama ezinga, inye ixabisa iwaka leerandi (R1000). Angachitha kangangamawaka amahlanu (R5000) Yenza umlinganiselo weenkomo zobisi nowenkomo zenyama.

Section (a)(iii) on the other hand reads as follows:

Ingaba iinkomo zobisi nezenyama zingasinika owuphi umlinganiselo? Chaza.

Perhaps there was no need to use the word 'ezinga' in section (i). Another problem in section (a)(i) is that a mathematical term - inequality - was translated. The technical term inequality was translated as umlinganiselo [unequal things]. The term 'umlinganiselo' has a connotation of inequality, but it does not necessarily have the same meaning as inequality in mathematics. This implies that it might be hard for mathematics learners whose home language is isiXhosa to interpret the task and realise that they must write an inequality. It is pertinent to note that in as much as the translation referred to the word 'umlinganiselo' consistently for inequalities in parts (a)(i) and (a)(ii), it was again used in section (a)(iii). However, the term inequality does not appear in the original version in section (a)(iii). This means the isiXhosa version here is different from the original version. When the translated version is totally different from the original one, then the two are more likely to inevitably yield different results. In section (b), the original version demands graphical representation of inequalities on the $x y$-plane. But the isiXhosa version on the contrary does not mention the word 'umlinganiselo', which then suggests that the two versions call for dissimilar outcomes. The literal translation of 'umlinganiselo' in English is measurement. This meaning is not equivalent to that of an inequality. This reinforces the idea that translating technical terms is unnecessary.

\section{Task in Sepedi}

Unlike in the other two translations (isiZulu and isiXhosa), the Sepedi version demonstrates some degree of consistency in sections (a)(i) and (a)(iii) for the use of the expression tše sa tsebjego (unknown) for both $x$ and $y$. Because $x$ and $y$ are both unknowns, this translation is correct and meaningful. In section (a)(i) the word tekatekanyetšo [measurement] is used for the word inequality, and that refers to the concept of measurement when used loosely. This word 'tekatekanyetšo' is not a proper translation for the mathematical term inequality. The translation of the word inequality has been extremely inconsistent in this language. For instance, in (a)(i) the word inequality is translated as tekatekanyetšo, while in (a)(ii) the word inequalities is translated as ditšhitišo [obstacles or constraints], and in (b) it is translated as mo di kopanago [where they meet]. This inconsistency has a potential to confuse the actual the meaning of the task. The three stated terms for inequality do not even mean the same thing. Each term has its own distinct meaning. These terms do not even refer to inequality in mathematics. Again, the translation of technical terms in this language was not necessary.

\section{Task in Sesotho}

In the Sesotho version, the variables $x$ and $y$ were not translated in both parts (a)(i) and (a)(iii). Yet it can be said that the translation makes a lot of sense. Section (a)(i) reads as follows: 'Rapolasi o reka dikgomo tsa lebese ... le likgomo tsa nama ...' [A farmer buys dairy cows ... and beef cows ...]. This is done without alluding to the number of cows $(x$ and $y)$. It is important to realise that when solving the problem, learners might still refer to the use of any two variables (not necessarily $x$ and $y$ ): one for dairy cows and the other for beef cows. In the Sesotho version, the translation for the term inequality is consistently referred to as kgaello [shortage] throughout the task. The word kgaello in Sesotho means shortage of a certain quantity. As such the translation does not necessarily match the original use of the term (inequality). The use of the term kgaello for inequality distorts the original meaning of the task. Perhaps the technical terms should have been left intact during translation.

\section{Learners' reflections on the home language versions of the task}

As part of the reflections on the lesson proceedings, learners were requested to mention their views on the use of the translated tasks. In general, learners stated that since it was their first encounter, they found it challenging to do the translated task. Learners felt that the task in their home languages was unclear and they therefore would prefer the English version. It was hoped that the teacher would probe further on learners' comments.

\section{Conclusion}

The findings in this article point out that the process of translating mathematical tasks is a complex activity. The process of translating a mathematics task to learners' languages was done by unprofessional translators (teachers in the language department). That compromised the quality of such translation. The teachers who helped the participating teacher in this study with translation are not acquainted with mathematics as a learning area. As a result, they translated variables and technical terms, which distorted the meaning of the original task. This could be avoided by engaging professional translators and qualified mathematics educators in the process. In a study where a translated task was used in class, Sepeng (2014, p. 20) found that there was no significant difference in the way learners engaged with the task in both English and isiXhosa. This suggests that it might be necessary to carry out more studies on translating mathematics tasks. 
The lesson drawn from this study points to a need for a deliberate effort to translate mathematics tasks even from other topics to help learners have access to mathematics content in their mother tongue. However, such translation must be done by professional translators to ensure a more robust process. Again, such translation must not be left to individual educators but should be done at the national level so that all schools could be given such tasks as part of instructional resources.

\section{Acknowledgements}

I would like to thank the teacher who participated in this study and the Gauteng Department of Education for the permission to carry out this study.

\section{Competing interests}

The author has declared that no competing interest exists.

\section{Author's contributions}

The author has contributed alone to this work.

\section{Ethical considerations}

Ethical clearance was obtained from the Gauteng Department of Education.

\section{Funding information}

This study was partially funded by the Canon Collins Trust scholarship.

\section{Data availability}

Data sharing is not applicable to this article as no new data were created or analysed in this study.

\section{Disclaimer}

The views and opinions expressed in this article are those of the author and do not necessarily reflect the official policy or position of any affiliated agency of the author.

\section{References}

Adler, J. (2001). Teaching mathematics in multilingual classrooms. Dordrecht: Kluwer

Aoyama, R. (2020). Exploring Japanese High School Students' L1 Use in Translanguaging in the communicative EFL classroom. The Electronic Journal for English as a Second Language, 23(4), 1-18.

Barwell, R. (2003). Linguistic discrimination: An issue for research in mathematics education. For the Learning of Mathematics, 23(2), 37-43.

Barwell, R. (2016). Investigating stratification, language diversity and mathematics classroom interaction. PNA, 11(1), 34-52.

Bryman, A. (2008). Social research methods (3rd ed.). Oxford: Oxford University Press

Chibamba, M. (2018). Translation and communication for development: The case of a health campaign in Zambia. The Translator, 24(4), 301-317. https://doi.org/10.10 80/13556509.2019.1586069

Cohen, L., \& Manion, L. (1994). Research methods in education. London: Croom Helm.
Costley, T., \& Leung, C. (2020). Putting translanguaging into practice: A view from England. System, 92, 102270. https://doi.org/10.1016/j.system.2020.102270

Department of Basic Education (DBE). (2011). Curriculum and assessment policy statements Grades 10-12. Pretoria: DBE.

García, O. (2009). Bilingual education in the 21st century: A global perspective. Malden, MA: Wiley-Blackwell.

Luneta, K. (Ed.). (2018). Teaching mathematics foundation to senior phase (2nd ed.). Cape Town: Oxford University Press South Africa.

Marais, K. (2014). Translation theory and development studies - A complexity theory approach. Abingdon-on-Thames: Routledge.

Moschkovich, J. (1999). Supporting the participation of English language learners in mathematical discussions. For the Learning of Mathematics, 19(1), 11-19.

Moschkovich, J. (2002). A situated and sociocultural perspective on bilingual mathematics learners. Mathematical Thinking and Learning, 4(2 \& 3), 189-212. https://doi.org/10.1207/S15327833MTL04023_5

Moschkovich, J.N. (2009). How language and graphs support conversation in a bilingual mathematics classroom. In R. Barwell (Ed.), Multilingualism in mathematics classrooms: Global perspectives (pp. 78-96). Bristol: Multilingual Matters.

Mouton, J. (2001). How to succeed in your master's and doctoral studies. A South African guide and resource book. Pretoria: Van Schaik Publishers.

Mpalami, N. (2013). Understanding and using mathematical representations: A case study of prospective primary school educators in Lesotho. Unpublished PhD thesis, Dublin City University.

Nhongo, R., \& Tshotsho, B.P. (2019). Translanguaging as an instructional method in science and mathematics education in English second language classroom contexts. The Independent Journal of Teaching and Learning, 14(2), 57-71.

Nord, C. (1997). Translating as a purposeful activity: Functionalist approaches explained. London: Routledge.

Planas, N., \& Setati-Phakeng, M. (2014). On the process of gaining language as a resource in mathematics education. ZDM, 46(6), 883-893. https://doi. org/10.1007/s11858-014-0610-2

Purwadi, I.M.A., Sudiarta, I.G.P., \& Suparta, I.N. (2019). The effect of concretepictorial-abstract strategy toward students mathematical conceptual understanding and mathematical representation on fractions. International Journal of Instruction, 12(1), 1113-1126. https://doi.org/10.29333/iji.2019. 12171a

Saal, P.E., Van Ryneveld, L., \& Graham, M.A. (2019). The relationship between using information and communication technology in education and the mathematics achievement of students. International Journal of Instruction, 12(3), 405-424. https://doi.org/10.29333/iji.2019.12325a

Sahr, A. (2020). Translanguaging practices of multilingual learners of German. Athens Journal of Education, 7(1), 49-76. https://doi.org/10.30958/aje.7-1-3

Sayer, P. (2013). Translanguaging, TexMex, and bilingual pedagogy: Emergent bilinguals learning through the vernacular. TESOL International Association, 47(1) 63-88. https://doi.org/10.1002/tesq.53

Sepeng, P. (2014). Use of common-sense knowledge, language and reality in mathematical word problem solving. African Journal of Research in Mathematics, Science and Technology Education, 18(1), 14-24. https://doi.org/10.1080/102884 57.2014 .890808

Setati, M. (2003). Speaking mathematics: Language(s), discourses and cultural models in a multilingual mathematics classroom in South Africa. Proceedings of the 11th Annual SAARMSTE Conference. University of Swaziland, Kwaluseni, 11-15 January.

Setati, M. (2005a) Teaching mathematics in a primary multilingual classroom. Journa for Research in Mathematics Education, 36(5), 447-466.

Setati, M. (2005b) Researching teaching and learning in school from "with" or "on" educators to "with" and "on" educators. Perspectives in Education, 23(1), 91-101.

Setati, M. (2008). Access to mathematics versus access to the language of power: The struggle in multilingual mathematics classrooms. South African Journal of Education, 28, 103-116.

Setati, M., \& Barwell, R. (2006). Discursive practices in two multilingual mathematics classrooms: An international comparison. African Journal for Research in Mathematics, Science and Technology Education, 10(2), 27-38. https://doi.org/ 10.1080/10288457.2006.10740602

Stein, M.K., Grover, B.W., \& Henningsen, M. (1996). Building student capacity for mathematical thinking and reasoning: An analysis of mathematical tasks used in reform classroom. American Educational Research Journal, 33(2), 455-488. https://doi.org/10.3102/00028312033002455

Tesseur, W., \& Crack, A. (2020). 'These are all outside words': Translating development discourse in NGOs' projects in Kyrgyzstan and Malawi. Journal for Translation Studies in Africa, 1, 25-42. https://doi.org/10.38140/

Tshuma, L. (2020). The language issue in the teaching of mathematics in South Africa (1st ed.). Stellenbosch: African Sun Media.

Webb, L., \& Webb, P. (2008). Introducing discussion into multilingual mathematics classrooms: An issue of code switching. Pythagoras, 67, 26-32. https://doi. org/10.4102/pythagoras.v0i67.71 